\title{
Escritas em erupção: a ruína \\ da mulher, a ascensão da barata - \\ a desconstruçâo identitária pela via \\ do apagamento da identidade humana
}

Maria Edinara Leão Moreira (UNIFRA)

Recebido 13 ago. 2013/Aprovado 22 abr. 2014

\begin{abstract}
Resumo
A presença da barata acentua o drama de consciência vivido por G. H. nesse que é um tipo de "rito de passagem". Os ritos de passagem costumam vir carregados de crises e associam-se mais ao olhar antropológico, que poderia trazer outra iluminação ao dilema existencial vivido pela personagem, confirmando a experiência como uma superação de etapas, baseada na causalidade do antes e do depois. A personagem vive sua paixão, a via-crúcis do abandono e da dissolução para, num momento posterior, reencontrar dentro de si mesma o gênero humano. A presença da barata acentua o drama de consciência vivido por G. H. nesse "rito de passagem". G. H. perfaz um caminho oposto ao da cultura. Entre o nojo e o encantamento, a personagem consegue identificar em si uma força primordial que alimenta o humano que somos, $e$ é nessa direção que ela se move, buscando reunificar o sujeito às forças míticas da natureza. No momento em que ingere a barata, funde-se com o mundo primário que, segundo afirma, incorpora as temporalidades das civilizações passadas.
\end{abstract}

Palavras-chave: drama da linguagem; existência; experiência; dissolução; gênero humano. 
Em A paixão segundo G. H., o deslocamento do sujeito pode ser verificado, mais claramente, desde o momento em que a narradora deixa a mesa do café e se dirige ao quarto de empregada. A partir desse ponto, o discurso passa a referenciar a própria personagem, continuamente reiterada, à medida que a narrativa acompanha os seus passos, que parecem se dirigir ao oposto das certezas que até então ela sustentava. A despersonalização da personagem a leva a ir perdendo, gradativamente, o vínculo emocional que a liga aos humanos, da mesma forma que sua identificação com o que pensava ser vai se apagando, até que ela já não se reconhece na mulher que assinava G. H. nas valises. Este artigo, portanto, trata do sujeito G. H. em sua diversa relação com a barata, o outro desconhecido de si, provocador do descontrole que vai culminar na perda das desconstruções identitárias.

No momento em que G. H. revela seu encontro com a barata, dá-se a representação do "outro" fora de sua espécie, e a situação narrativa aumenta em dramaticidade. O instante em que a barata aparece é carregado de tensão, pois G. H. se assusta quando a vê ao fundo do guarda-roupa instalado no quarto da empregada.

O impacto do instante em que a barata se torna visível é tão forte que a protagonista refere que seu coração embranquece de susto. O vocábulo "embranquece" forma uma imagem metafórica de apreensão e retenção do tempo: “De encontro ao rosto que eu pusera dentro da abertura, bem próximo de meus olhos, na meia escuridão, movera-se a barata grossa. Meu grito foi tão abafado que só pelo silêncio contrastante percebi que não havia gritado. O grito ficara me batendo dentro do peito" (LISPECTOR, 1979, p. 43). Aqui é demarcado o instante da percepção visual, quando a barata aparece delimitada linguisticamente: não se tratava de "uma" barata, era "a" barata. O susto abafa o grito, que ficara sufocado na ausência da corrente de som.

Em meio a tais pensamentos, ainda parada no quarto, G. $H$. ouve a estranha movimentação da barata, começando pelo "tremor das antenas", até que consegue vê-la: sua cor é parda e seu movimo, lento como o de quem carrega sobre si um pesado fardo. Nesse momento, G. H. é tomada por uma alegria de quem percebe a coragem dentro de si, advinda, talvez, do próprio medo. Ela sente dentro de si a força do instinto "ruim, total e infinitamente doce" (LISPECTOR, 1979, p. 49), sente o ódio e vem-lhe, de sua própria natureza, o desejo de matar. G. H. sente-se eufórica diante do ato que começa a praticar:

Sem nenhum pudor, comovida com minha entrega ao que é um mal, sem nenhum pudor, comovida, grata, pela primeira vez eu estava sendo a deconhecida que eu era - só que desconhecer-me não me impediria mais, a verdade já me ultrapassara: levantei a mão como para um juramento, e num só golpe fechei a porta sobre o corpo meio emergido da barata - _ - . - - (LISPECTOR, 1979, p. 49). 
O inseto, que surge inesperadamente, desperta na protagonista o desejo de matar, uma fúria reprimida em razão da sociedade. E, no avanço narrativo, processa-se um febril ritual de sedução: "Eu estava sendo seduzida [...]. A barata é pura sedução" (LISPECTOR, 1979, p. 56). Fúria e sedução, repulsa e fascínio são sensações ambíguas que a barata aviva em G. H.; avançando para a barata, a mulher quer estabelecer um vínculo com suas raízes, quer saber de si através do outro. Não conseguindo matá-la, é obrigada a olhar a barata, pela qual vai crescendo uma admiração, que aumenta e se transforma numa aceitação silenciosa, quase num pacto. $\mathrm{O}$ fato de a barata continuar viva dilui a resistência da protagonista, e ela se entrega à vertigem de viver o inusitado e disforme. Vive sua paixão, a via-crúcis do abandono e da dissolução para, num momento posterior, reencontrar dentro de si mesma o gênero humano: "era uma lama onde se remexiam com lentidão insuportável as raízes de minha identidade" (LISPECTOR, 1979, p. 53); "Para ter chegado a isso, eu abandonava a minha organização humana - para entrar nessa coisa monstruosa que é minha neutralidade viva" (LISPECTOR, 1979, p. 98).

A presença da barata acentua o drama de consciência vivido por G. H. nesse que é um tipo de "rito de passagem", o qual costuma sempre vir carregado de crises. Os ritos de passagem associam-se mais ao olhar antropológico, que poderia trazer outra iluminação ao dilema existencial vivido pela personagem, confirmando a experiência como uma superação de etapas, baseada na causalidade do antes e do depois. Isso posto, talvez possamos nos referir tanto à barata quanto ao quarto da empregada como instâncias espaciais desse rito: "A passagem estreita fora pela barata difícil, e eu me havia esgueirado com nojo através daquele corpo de cascas e lama [...]" (LISPECTOR, 1979, p. 61). A barata, embora represente o "outro", o "estranho", contém em si algo que habita G. H., a "matéria primordial", o "elemento vital que liga as coisas", o "inexpressivo", o "neutro", pois "o que nela [na barata] é exposto é o que em mim eu escondo: de meu lado a ser exposto fiz o meu avesso ignorado". (LISPECTOR, 1979, p. 73)

G. H. perfaz um caminho oposto ao da cultura. Entre o nojo e o encantamento, a personagem consegue identificar em si uma força primeva que alimenta o humano que somos, e é nessa direção que ela se move, buscando reunificar o sujeito às forças míticas da natureza. No momento em que ingere a barata, funde-se com o mundo primário, que, segundo afirma, incorpora as temporalidades das civilizações passadas, desde que os grandes sáurios se extinguiram, abrindo espaço para os mamíferos (cf. FREUD, 2010, p. 49). Ao longo dos séculos, a barata não sofreu mutações, ela se conserva a mesma espécie desde o tempo extinto dos sáurios. De acordo com Nunes (1995), "[...] a barata 'real', o mero inseto doméstico - Periplaneta americana (Linneus), do gênero dos 
ortópteros e da família dos blastídeos [...], o inseto do romance de Clarice Lispector nada possui de alegórico". (p. 60)

A partir do contato com a barata, G. H. passa a sofrer um processo de retorno pessoal, que lhe impõe a dolorosa atitude de renúncia, uma conversão radical, tendo de abrir mão de um mundo anterior, de aparências e de falta de autenticidade. Em meio a esse sacrifício, a essa paixão, percebendo que as palavras falham quando tenta expressar o que vive, G. H. passa por momentos de grande inquietação. Assim, ela parece entrar em outra forma de vida - "eu já entrara a tal ponto na natureza da barata" (LISPECTOR, 1979, p. 82) -, em que a identidade é desconhecida, provocando algo de estranhamento, uma liberação da moralidade, para entrar em algo que não sabe o que é. Bessiere (1995) refere que

aquilo que fala de alguma coisa deve ser uma coisa distinta daquilo de que fala. E, no entanto, a partir do momento em que fica fora do enunciado de realidade, a obra fala de fato de alguma coisa e é aquilo de que fala. É um processo que se finaliza e se funda a si próprio; tematiza alguma coisa diferente de si ao mesmo tempo que a si própria. (p. 389)

Por fim, a protagonista acaba por ceder a essa realidade impessoal, conforme assinala Berta Waldman (1992): “Assim, o papel que a barata desempenha é o de desmoronar o sistema dentro do qual a narradora vive" (p. 76). G. H. vai percebendo a estrutura interna da barata, as camadas e cascas de que é composta. À medida que a barata perde a casca, expelindo a branca secreção, parece ficar mais aparente para a protagonista a sua própria essência, contrapondo, em certo sentido, a renúncia ao próprio ser e a entrega imediata ao silêncio. Desde que vê, subitamente, a barata saindo do armário, G. H. sente uma náusea, mal-estar que a motiva a avaliar a vida de que tanto cuidara: uma vida óbvia, difícil, obscura. Ver a barata no quarto representa o momento de iluminação, o que a faz sentir-se outra:

Eu, corpo neutro de barata, eu com uma vida que finalmente não me escapa pois enfim a vejo fora de mim - eu sou a barata, sou minha perna, sou meus cabelos, sou o trecho de luz mais branca no reboco da parede - sou cada pedaço infernal de mim - a vida em mim é tão insistente que se me partirem, como a uma lagartixa, os pedaços continuarão estremecendo e se mexendo. (LISPECTOR, 1979, p. 61)

Essa metáfora simboliza o motivador de uma longa e difícil avaliação da existência e mostra que a narradora não se considera, pelo menos até esse instante, alguém tão inconsciente da própria solidão, uma condição que tem em comum com a barata. O horror que mostra pelo inseto a desafia, obrigando-a a vencer o nojo e o susto para dele aproximar-se. Prestes a ruir no silêncio petrificado, no ato de entregar-se ao outro, de render-se à massa branca do inseto, a protagonista entra em comunhão consigo mesma. Porém, na experiência de G. H., "a manducação da bara- 
ta, protótipo da matéria-prima do mundo, produz pelo mesmo efeito de transformação, mas invertido, a redução da personalidade de G. H. ao nível da pura matéria viva" (SÁ, 1988, p. 217). A partir dessa provação, enxerga-se, percebe sua náusea física e existencial que resulta em uma revelação: “De nascer até morrer é o que eu chamo de humana, e nunca propriamente morrerei". (LISPECTOR, 1979, p. 61)

A barata concentra o que há de mais repulsivo ao ser humano, é uma larva que se pisa sem remorso. "Olhei: a barata era um escaravelho. Ela toda era apenas a sua própria máscara. Através da profunda ausência de riso da barata, eu percebia a sua ferocidade de guerreiro. Ela era mansa mas sua função era feroz" (LISPECTOR, 1979, p. 112). Entretanto, passada a primeira impressão, G. H. redescobre a barata como um ser que habita o quarto potencialmente vivo, uma barata "imemorial" (LISPECTOR, 1979, p. 43), que habitava a terra mesmo antes dos dinossauros. Segundo a narradora, as baratas são as testemunhas do carvão às geleiras e representam a resistência:

Eu sabia que baratas resistiam a mais de um mês sem alimento ou água [...]. E que, mesmo depois de pisadas, descomprimiam-se lentamente e continuavam a andar. Mesmo congeladas, ao degelarem, prosseguiam a marcha. Há trezentos e cinquenta milhões de anos elas se repetiam sem se transformarem. Quando o mundo era quase nu elas já o cobriam vagarosas. (LISPECTOR, 1979, p. 44)

Não se sabe por que o animal escolhido para mover a paixão de G. H. é a barata, o que a narradora mostra na condição da barata é anterioridade à espécie humana, gerando um supremo contraste: a barata, aparentemente frágil, diante da mulher, se fortalece, enquanto a mulher, aparentemente forte, capaz de matar, se fragiliza diante da ancestralidade e do poder de sobrevivência em condições totalmente desfavoráveis do inseto. A barata é o elemento iniciador, que vai permear a experiência da protagonista. Inicialmente, obriga-a a olhar para dentro de si, desestabilizando seu cotidiano. Assim, mostra a desordem, e G. H. caminha sem saber aonde chegar. O primeiro passo desencadeado na narrativa é o laço que a personagem firma com o inseto: ela "sai de si" para unir-se à barata, culminando no ato proibido de comer o imundo, absorvendo a massa branca. A fusão momentânea com o corpo da barata assinala uma incorporação de outra espécie de matéria, que vai ser assimilada no estágio da consciência de si.

Segundo narra, G. H. continua em frente à barata, percebendo-a como um organismo vivo, organizado como uma pessoa. A personagem havia entrado no território da desorganização, que agora denomina "identidade". Entretanto, entrar nesse estágio de conhecer-se a ponto de saber quem é demanda coragem, artifício que ela não possui, e por isso confia na covardia como forma de voltar à sua reorganização, conforme consta no início da narrativa. 
Para a protagonista, a covardia será o antivalor que a conduzirá à salvação. Eis aí não o reflexo, mas o antirreflexo da sociedade, uma espécie de representação pela negação.

À luz do sol, G. H. agora vê a barata como um animal feio, com sua boca sem dentes. Ninguém, que não fosse também uma barata, teria prazer em estar na presença de uma barata. É o que a personagem pensa para, depois, questionar quem a quereria naquele momento, em que se revelava a mesma figura desenhada na "pedra de uma caverna" (LISPECTOR, 1979, p. 92) com um homem e um cachorro. A circularidade da linguagem diz respeito a esse instante em que tudo serve, uma vez que nada em definitivo pode servir: "Dentro dos sons secos de abóbada tudo podia ser chamado de qualquer coisa, porque qualquer coisa se transmutaria na mesma mudez vibrante" (LISPECTOR, 1979, p. 92). A comunicação não se efetiva porque se chega ao momento do retorno à natureza, em que as coisas são em seu absoluto, são um estágio anterior à cultura e, por isso, lhe escapam. Freud (2010), ao abordar a questão da cultura, refere "o sentimento de culpa como o problema mais importante no desenvolvimento da cultura [e de demonstrar que] o preço do progresso cultural é pago com a perda da felicidade devido à intensificação do sentimento de culpa". (p. 163)

No entanto, apesar de todo nojo ancestral de baratas, quando penetra no fundo infernal de si mesma, G. H. confessa: “Estou somente amando a barata. Ee um amor infernal" (LISPECTOR, 1979, p. 111). Como efeito da minuciosa observação, superado o nojo, G. $\mathrm{H}$. passa a amar a barata, e nem mesmo a própria personagem entende como se deu essa transformação: "compreende-me porque eu não estou me compreendendo" (LISPECTOR, 1979, p. 111). A incompreensão faz com que perceba coisas mudando dentro de si: "perder os invólucros da lagosta faz frio" (LISPECTOR, 1979, p. 111). Cada um tem seus processos internos, seus medos, seus invólucros, suas camadas e camadas de casca, das quais é doloroso sair. Dói romper com a zona de conforto, onde as coisas estão ajustadas, e descortinar o novo, com todos seus riscos, onde "faz frio" e se perde o aconchego.

Ainda que a protagonista houvesse matado a barata, morte de inseto não é considerado crime para os humanos, apenas acelera a percepção, para nós leitores, do instinto mais brutal do homem. G. H. vê irromper dentro de si uma força desconhecida, um impulso assassino e se coloca diante de outra lei, a lei da matéria viva, segundo a qual matar um inseto pode, sim, ser considerado crime, porque matar a barata é subverter a ordem da vida, é uma transgressão contra a lei. Não obstante, havia a necessidade de manter a ordem e de redimensionar o sentido da palavra "amor", possivelmente, o sentimento da barata em sua luta pela vida, enquanto estava presa no armário. 
Assim, G. H. confessa estar abandonando o que a liga à antiga humanidade - a esperança, a beleza, a redenção - e conclui que a vida estava desde sempre no neutro, o que inspirava medo. Não apenas a raça humana sente medo, mas somente ela possui medos imaginários. O medo é considerado comum entre os humanos e, por causar desconforto à pessoa, torna-se indigno deste ser. Afastado como um sentimento medíocre, não traz qualquer retorno positivo ao indivíduo, deixando-o de mãos vazias, lastimoso e sem consolo. Segundo Santiago (2004), "o medo se exprime pela oferta fraudulenta ao solicitante de algo que, acredita, lhe é exterior, embora a raiz mais poderosa cresça no seu íntimo. $\mathrm{O}$ medo é decepcionante e autodecepcionante" (p. 206). O medo congrega a experiência de rejeição e de autorrejeição, podendo ter efeito devastador no homem, tanto na recusa interna em aceitar a coisa errônea quanto no movimento externo de remessa incorreta da coisa solicitada. Portanto, "o medo é o elemento imobilizador do delírio ficcional na escrita audaciosa. Funciona de maneira semelhante ao borrifo de gás imobilizante, de que se vale o assaltado diante do horror que o assaltante lhe inspira". (SANTIAGO, 2004, p. 174)

No quarto, o espaço e o tempo desarticulados pressionam $\mathrm{G}$. $\mathrm{H}$., sem lhe dar passagem livre, e o sol lhe provoca ardência nas têmporas. Destacamos que o fechamento em torno da personagem é expresso pelas palavras "canto", "encurraladas", "fechar", "formo" "recuou" e "irremediável" (LISPECTOR, 1979, p. 46). Assim se firma a consciência do perigo, o perigo invisível que permeia a condição de existir, e que a personagem fingira, pela vida inteira, não ver, mas agora "tinha a responsabilidade alucinada de ter de saber disso" (LISPECTOR, 1979, p. 47). Redobrara a atenção, porque a atenção acompanha a vida e, nos atos de espera, acentua-se. G. H. constata, ao olhar a vida da barata, que a barata vive seu tempo com a máxima atenção; na barata, o estar atento é o único "sentimento"; a barata vive com o único objetivo de se manter viva.

Nesse momento de progressão da experiência da sua paixão, G. H. já não pode voltar atrás - é "o medo de quem já entrou" (LISPECTOR, 1979, p. 91) -, tampouco sentir o medo humano: "era medo da minha falta de medo" (p. 91). Todavia, há o pressentimento de estar sujeita a algo terrível. Diante disso, ela pede que não a deixem presa no quarto com a barata, porque retrocede e já não quer "as outras espécies!" (LISPECTOR, 1979, p. 91), somente as pessoas. Eis aí mais uma tentativa de fuga. A sequência da narrativa comprova que qualquer tentativa de mudança é impossível, pois, quando a personagem arrisca voltar atrás, o oratório aumenta de intensidade, impedindo o movimento. Em outras palavras, a narrativa se petrifica, tanto quanto a atuação da personagem: "sem tentar mais fazer um movimento para me ajudar. Eu já havia abandonado a mim mesma" (LISPECTOR, 1979, p. 91). À essa altura, a personagem já está distante do seu corpo, 
sequer ouve a si mesma, embora ainda não tenha se desligado completamente dele.

G. H. olha a barata, sabendo dela muito mais do que antes sabia. Lembra-se do episódio narrativo do deserto da Líbia e pensa na antiguidade do inseto como habitante do planeta: "A barata que lá me precedera de milênios, e também precedera aos dinossauros. Diante da barata, eu já era capaz de ver ao longe Damasco, a cidade mais velha da terra". (LISPECTOR, 1979, p. 109)

Quando refere pela primeira vez o desejo de comer a barata, a personagem - "a barata é comível como uma lagosta, a barata era um crustáceo" (LISPECTOR, 1979, p. 109) - a questão do nojo vem à tona. Sentimos nojo do desconhecido, do estranho e alheio a nós. De modo geral, tal sensação também serve para nos proteger dos perigos, atuando como uma barreira de proteção: "o nojo me guia e me fecunda" (LISPECTOR, 1979, p. 109). O nojo, uma das reações mais ancestrais do homem, revela sua primitividade, "está dentro" desde sempre, participa do espaço semiótico. Liberto o desejo de morte, a pulsão - elemento universal entre os humanos - faz da escultora de classe média-alta uma vivente comum, dotada da mesma estrutura de que são feitos os mortais.

A narradora traz o drama da personagem na delimitação de seus universos, situação suscitada pelo encontro com a barata, um inseto sem mistificação nem alegoria. Essa experiência infernal terá sido para G. H. um processo de transformação interior consumada, o segredo revelado da consciência solitária, entre um período de ruptura e um período de retorno, intercalado por silêncios, paradoxos, metáforas na busca do autoconhecimento. Desse modo, ao provar a massa branca da barata, G. H. se submete ao sacrifício máximo, de modo a experimentar a purificação. A falta de condições de constatar o "neutro" a leva a rejeitar a massa branca do inseto: "[...] comecei a cuspir, a cuspir furiosamente aquele gosto de coisa alguma, gosto de um nada que no entanto me parecia quase adocicado como o de certas pétalas de flor, gosto de mim mesma - eu cuspia a mim mesma, sem chegar jamais ao ponto de sentir que enfim tivesse cuspido minha alma toda". (LISPECTOR, 1979, p. 167)

Ao cuspir a massa branca da barata, G. H. parece negar a própria essência, demonstrando compreender sua limitação. Entretanto, ao unir-se à barata, vive a entrega ao mundo desconhecido: "A gradual deseroização de si mesmo é o verdadeiro trabalho que se labora sob o aparente trabalho, a vida é uma missão secreta" (LISPECTOR, 1979, p. 174). O termo "deseroização", criado pela autora, agregando à palavra herói o prefixo "des", traduz outra face da personagem, na medida em que apresenta o herói pelo avesso. No caso de G. H, há, ainda, a busca por uma "neutralidade" dos próprios sentidos, revelada no campo semântico de palavras como "neutro", "atonal", "insosso", "inexpressivo" e "silêncio". 
Na narrativa, G. H. revela, inicialmente, sua condição existencial, referindo ser, antes de tudo "mulher"; depois, assume-se como mulher frente à barata - ela e o outro remoto de si -; por fim, após a metamorfose com a barata, sintetizando o drama simbólico da própria existência, permanece mulher. Nessa estranha peripécia, procura algo, em um ritual que assinala a própria metamorfose, de uma condição para outra, que pode ser interpretado como de borboleta a crisálida, tanto quanto de crisálida a borboleta. Também é possível conferir à personagem a renovação da existência, oriunda da necessidade de mudanças, de caráter orgânico ou psicológico, que qualquer pessoa pode sentir. No momento em que vivencia a transposição, G. H. parece experimentar uma catástrofe, visto que se permite ter acesso ao avesso, à contraditoriedade, à decomposição. Eis, portanto, coerentes justificativas para seu enjoo e - por que não? - seu nojo diante de alguns aspectos relacionados à vida.

Com o corpo já transformado em barata, G. H. degusta o silêncio dos séculos, como um silêncio de barata que olha, sentindo o mundo: "O mundo se me olha" (p. 62). O mundo dá e recebe este olhar: "Tudo olha para tudo, tudo vive o outro; neste deserto as coisas sabem as coisas" (LISPECTOR, 1979, p. 62). Há, nessa expressão, complementaridade no mundo da matéria viva e o saber de quem vibra no outro sua intensidade vital.

G. H. não consegue prever onde vai dar sua transformação: "É que por enquanto a metamorfose de mim em mim mesma não faz nenhum sentido. É uma metamorfose em que perco tudo o que eu tinha, e o que eu tinha era eu - só tenho o que sou" (LISPECTOR, 1979, p. 63). Como nos revela o trecho, a protagonista sabe que já é algo diferente de sua anterior formulação, mas não sabe ainda o que pode vir a ser.

Enquanto usa como veículo o corpo da barata, G. H. diz estar deixando o espaço do quarto para seguir por desertos e lugares cada vez mais longínquos. O espaço refrata-se mais uma vez, e a personagem vê desabar seu edifício de estrutura pesada. Assim, ela, pessoa, não mais em corpo de barata - "G. H. até nas valises" (LISPECTOR, 1979, p. 65) -, assiste toneladas caindo dos escombros sobre areias. E nisso há júbilo: "As coisas haviam voltado a ser o que eram" (p. 65). As coisas voltam a sua vida anterior, e G. H. pensa que "todo caso de loucura é que alguma coisa voltou. Os possessos, eles não são possuídos pelo que vem, mas pelo que volta" (LISPECTOR, 1979, p. 66). Nesse trecho, recorrente em nossa análise, notamos que o recalque de alguma coisa incompreendida e não assimilada é que traz à tona a loucura: "E isso parecia o inferno, essa destruição de camadas e camadas arqueológicas" (p. 66). O inferno de G. H. seria, pois, a desumanização, a perda do sentimento humano.

Uma vez operada a separação entre G. H. e a barata, ambas mantêm sua individualidade: "Sem um grito olhei a barata. Vista 
de perto, a barata é um objeto de grande luxo. Uma noiva de pretas joias. É toda rara, parece um único exemplar. Prendendo-a pelo meio do corpo com a porta do armário, eu isolara o único exemplar" (LISPECTOR, 1979, p. 67). Nessa passagem, a barata deixa de ser abjeção transfigurada em objeto raro, de luxo, e presa pelo meio do corpo, lembra a situação da mulher. Presa e desprovida de seus direitos pela condição sexual, tem de carregar sua insígnia: "pois o que é esmagado pela cintura é fêmea" (LISPECTOR, 1979, p. 89). G. H., contudo, continua a rejeitá-la: “Eu, porém, não queria a parte que me coubera" (LISPECTOR, 1979, p. 67). A ideia de uma barata que segrega a dona da casa, ainda que no plano de construção metafórica, é, no mínimo, intrigante. Afinal, seria tão fácil eliminá-la. Mas "esta" barata não é apenas "uma barata"; ela nomeia a representação simbólica de algo que submerge por detrás do animal que se arrasta.

A metamorfose prescinde da morte, de modo que algo deve se extinguir para operar-se a transformação: “E via, com fascínio e horror, os pedaços de minhas podres roupas de múmia caírem secas no chão, eu assistia à minha transformação de crisálida em larva úmida, as asas aos poucos encolhiam-se crestadas. E um ventre todo novo e feito para o chão, em ventre novo renascia" (LISPECTOR, 1979, p. 71). Assim, G. H. deita-se na cama e a barata passa a olhá-la de cima para baixo.

Na expressão da narradora, "a barata é pelo avesso. [...]. O que nela é exposto é o que em mim eu escondo: de meu lado a ser exposto fiz o meu avesso ignorado" (LISPECTOR, 1979, p. 73). Tal revelação denota que o encontro de G.H com a barata a faz ver o reverso de si, e, sendo seu reverso, a barata seria também o seu espelho invertido. A barata mostra, então, o que a protagonista não desejaria ser, mas que a habita desde as profundezas do eu.

Há um limite difícil de ser mensurado entre G. H. e a barata: "Eu talvez já soubesse que, a partir dos portões, não haveria diferença entre mim e a barata" (LISPECTOR, 1979, p. 77). Diante dessa dificuldade, G. H. decide ficar no "dentro do que é" (LISPECTOR, 1979, p. 78), porque sabe que transcender transgride sua condição humana, porque a ultrapassa: "transcender era antigamente o meu esforço humano de salvação [...] Mas ficar dentro do que é, isso exige que eu não tenha medo". (p. 78)

Nesse instante narrativo, G. H. e a barata estão em nível de quase-igualdade: "Ah, pelo menos eu já entrara a tal ponto na natureza da barata que já não queria fazer nada por ela" (LISPECTOR, 1979, p. 82). Como sinal de libertação de conceitos antigos, por parte da protagonista, há um princípio de aproximação física entre ela e a barata: "A barata me tocava toda com seu olhar negro, facetado, brilhante e neutro. E agora eu começava a deixá-la me tocar [...]. Com nojo, com desespero, com coragem, eu cedia. Ficara tarde demais, e agora eu queria". (LISPECTOR, 1979, p. 84) 
Surge, nessa etapa narrativa, o reconhecimento da vida da barata na vida de G. H. e vice-versa, situação identificável pelo pronome "se", presente na passagem a seguir: "E também reconhecia a vigília da barata. A vigília da barata era vida vivendo, a minha própria vida vigilante se vivendo". (LISPECTOR, 1979, p. 86, grifo nosso)

Em A paixão segundo G. H., por um lado, a barata é comparada a uma pessoa: "E não apenas viva - como estava apenas viva aquela barata primariamente monstruosa - mas organizadamente viva como uma pessoa" (LISPECTOR, 1979, p. 95). Por outro lado, também a protagonista compara-se ao inseto: "Então, com cuidado como se já tivessem em mim partes paralisadas, fui-me deitando no colchão áspero e ali, toda crispada, adormeci tão imediatamente assim como uma barata adormece na posição vertical" (LISPECTOR, 1979, p. 100). Aqui há a ressalva de um "como se" para a metamorfose, mas, na sequência imediata da narração, encontramos uma definição definitiva: "minhas patas curtas se haviam agarrado, eu estremeci agora de frio. (p. 100)

Investida de barata, G. H. passa por muitas metamorfoses:

Eu crescera, e me tornara tão simples como uma rainha. Reis, esfinges e leões - eis a cidade onde vivo, e tudo extinto. Sobrei, presa por uma das pedras que desabaram. E, como o silêncio julgou a minha imobilidade como sendo a de uma morta, todos esqueceram-se de mim, foram embora sem se retirarem, e, julgada morta, fiquei assistindo. E vi, enquanto o silêncio dos que realmente haviam morrido ia-me invadindo como hera invade a boca dos leões de pedra. (LISPECTOR, 1979, p. 102)

Esse retrocesso a um tempo e a um espaço imemoriais denuncia uma tentativa de recompor os processos da barata, cujo corpo fora tomado por G. H. para empreender sua viagem. Assim, a protagonista pode fazê-la "com a falta de compromisso de quem não vai contar nem a si mesmo" (LISPECTOR, 1979, p. 102), sabendo-se "[...] talvez a primeira pessoa a pisar naquele castelo de ar [...], e que depois, erosada, se tornara uma área vazia onde depois de novo se tinham erguido as cidades que por sua vez se tinham erosado. Hoje o chão é amplamente povoado por diversas raças" (p. 102). Portanto, constatamos, por meio do trecho, que sobre os escombros das raças findas outras se formaram e também se extinguiram.

“De pé à janela, às vezes meus olhos descansavam no lago azul que talvez não passasse de um pedaço de céu" (LISPECTOR, 1979, p. 103). Para manter-se em pé à janela, G. H, habita, nesse momento, o corpo da barata, estando, pois, metamorfoseada em animal. Voltando à forma humana, senta-se novamente à cama e olha a barata, que "sabia de muito mais" (LISPECTOR, 1979, p. 108), haja vista o alcance de seu olhar. Eis, então, que o instinto sufocado retorna: "Eu estivera o tempo todo sem querer pensar no que já realmente pensara: que a barata é comível como uma 
lagosta, a barata era um crustáceo" (LISPECTOR, 1979, p. 109). Um instinto que volta várias vezes expõe um recalque e retoma à ideia do infamiliar exposta por Freud.

Agora, G. H identifica-se com a barata, falando por sua boca: "se tu puderes saber através de mim, sem antes precisar ser torturado, sem antes teres que ser bipartido pela porta de um guarda-roupa [...] então aprende de mim, que tive que ficar toda exposta e perder todas as minhas malas com suas iniciais gravadas" (LISPECTOR, 1979, p. 111). Vemos, aqui, a identidade de G. H. assimilada à da barata: "perder os invólucros de lagosta faz frio [...] compreende-me porque eu não estou me compreendendo [...]" (p. 111). G. H., formatada como barata, diz: "Se eu não disse, não foi por avareza de dizer, nem por minha mudez de barata que tem mais olhos que boca" (LISPECTOR, 1979, p. 113). Aqui a narradora antecipa algo que precisa externar, mas depois retrocede, confusa entre quem é o sujeito que fala, a mulher ou a barata, abreviando, assim, a dissociação da barata: “Oh, mas é a barata que vai morrer, não eu! não precisa desta carta de condenado numa cela..." (p. 113).

Há um momento que demarca a confusão entre os seres de G. H. e da barata. A primeira converte-se na outra para fazer a revelação crucial de toda uma vida: "Se eu não disse, não foi por avareza de dizer, nem por minha mudez de barata [...] Se eu não disse é porque não sabia que sabia - mas agora sei" (p. 113). A barata não revela o seu sentir por meio do recurso da fala, e sim pelos olhos, seu contato mais próximo com o mundo. Contudo, G. H. recua diante da revelação, que está latente em si. A barata, antes da morte, confessa: "Vou te dizer que eu te amo [...]. Estou precisando te dizer antes que eu..." (LISPECTOR, 1979, p. 113). Ao mesmo tempo em que, na pele da barata, faz essa afirmação, a protagonista tem um lapso de realidade, constatando que não - quem morre é a barata, e não ela própria. Ambas se debatem, a barata entre a vida e a morte; G. H. entre o que era e o que está se tornando.

Todas as vezes em que se assume como pressuposto a ocorrência de um desdobramento entre a personagem que se depara com a barata e uma outra, ocorre uma sequência de acontecimentos e questionamentos, na busca de compreensão, de internalização do verdadeiro eu de um ser frente ao inusitado. É como se estivesse a narradora-protagonista em seu estado de perda, de desconforto, obrigando-a ao vacilo diante da própria história, de suas bases culturais, principalmente, de sua consistência psicológica até então vivenciada. Somando-se a isso, valores, conceitos e lembranças pessoais lhe causam uma crise de silêncio e de paradoxos.

Desfeito o limite entre G. H. e a barata, ambas vivem o que chamam de intervalo: "Nesses intervalos nós pensávamos que estávamos descansando de um ser o outro. Na verdade era o grande prazer de um ser o outro: pois assim cada um de nós 
tinha dois" (LISPECTOR, 1979, p. 115); "A barata e eu aspiramos a uma paz que não pode ser nossa [...] E porque minha lama é tão ilimitada que já não é eu, e porque ela está tão além de mim" (LISPECTOR, 1979, p. 118).

No trecho a seguir, podemos observar que o humano constitui o máximo grau de prazer da natureza: "E eu dera o primeiro passo: pois o humano é uma sensibilização, um orgasmo da natureza [...]. Uma barata é maior que eu porque sua vida se entrega tanto a Ele que ela vem do infinito e passa para o infinito sem perceber, ela nunca se descortina" (LISPECTOR, 1979, p. 122). Num extremo sintoma de desagregação da personalidade, G. H. diz: "Eu não sou Tu, mas mim és Tu. Só por isso jamais poderei Te sentir direito: porque és Mim" (LISPECTOR, 1979, p. 126). E assim a própria protagonista sintetiza suas ações:

Eu fora obrigada a entrar no deserto para saber com horror que o deserto é vivo, para saber que uma barata é a vida. Havia recuado até saber que em mim a vida mais profunda é antes do humano - e para isso eu tivera a coragem diabólica de largar os sentimentos. Eu tivera que não dar valor humano à vida para poder entender a largueza, muito mais que humana, do Deus. Havia eu pedido a coisa mais perigosa e proibida? arriscando a minha alma, teria eu ousadamente exigido ver Deus? (LISPECTOR, 1979, p. 129)

Lemos, em A paixão segundo G. H., que a secura escaldante do deserto abrigava formas diferentes de vida, a vida pré-humana, anterior ao sentimento humano. Por isso G. H. se contorce em seu questionamento, quase súplica: "O que fizeste sou eu? e não consigo dar o passo para mim, mim que és Coisa e Tu. Dá-me o que és em mim. Dá-me o que és nos outros, Tu és o ele, eu sei, eu sei porque quando toco eu vejo o ele [...]. Eu, pessoa, sou um germe" (LISPECTOR, 1979, p. 133). Nessa intertroca, G. H. sentese o germe que é a barata e a barata se reveste de características humanizadas.

Segundo Freud (1996a), "o escritor criativo pode também escolher um cenário que [...] difere do mundo real por admitir seres espirituais superiores, tais como espíritos demoníacos ou fantasmas de mortos" (p. 267). Nesse sentido, G. H. é uma personagem que oscila entre mundos de natureza suprassensíveis, que evocam o espiritual.

Há um momento em que a tensão narrativa leva G. H. a perceber que $o$ ato insano de comer a barata seria sua única forma de redenção: "É que a redenção devia ser na própria coisa. E a redenção na própria coisa seria eu botar na boca a massa branca da barata" (LISPECTOR, 1979, p. 159). Apesar disso, ela não consegue reunir a coragem necessária para fazê-lo, como evidenciam os trechos a seguir: "desiludida comigo mesma, espantada com minha falta de força de cumprir o gesto que me parecia ser o único a reunir meu corpo à minha alma” (LISPECTOR, 1979, p. 160); “O 
que era pior: agora eu ia ter que comer a barata mas sem a ajuda da exaltação anterior, a exaltação que teria agido em mim como uma hipnose; eu havia vomitado a exaltação". (p. 160)

Mais adiante, a personagem repensa sua falta de coragem, dando-lhe outra interpretação:

Não. Eu não precisava ter tido a coragem de comer a massa da barata. [...] Entendi que eu já havia feito o equivalente de viver a massa da barata - pois a lei é que eu viva com a matéria de uma pessoa e não de uma barata.

Entendi que, botando na minha boca a massa da barata, eu não estava me despojando [...], mas estava de novo querendo o acréscimo. (LISPECTOR, 1979, p. 165)

Ao perceber que fora longe demais e vendo ruir sua estrutura psicológica, G. H. quer fazer o caminho de volta à sua vida humana, desejando esquecer o acontecido:

A despersonalização como a destituição do individual inútil - a perda de tudo o que se possa perder e, ainda assim, ser. Pouco a pouco tirar de si [...] as características. Tudo o que me caracteriza é apenas o modo como sou mais facilmente visível aos outros e como termino sendo superficialmente reconhecível por mim. Assim como houve um momento em que vi a barata e a barata é a barata de todas as baratas, assim quero encontrar em mim a mulher de todas as mulheres. [...]. Toda mulher é a mulher de todas as mulheres, todo homem é o homem de todos os homens. (LISPECTOR, 1979, p. 170)

Sua experiência é a mais radical das experiências, pois o contato com a realidade se dá por meio da ação de comer uma barata, ato que a devolve ao início da civilização, onde já não é possível continuar sendo réplica de si, porque a realidade é ordem imperativa. A contradição essencial dessa narradora pode ser constatada em sua aspiração ao silêncio, pois sabe que jamais poderá atingir o paradoxo de sair por um lugar que não tem saída.

Salientamos, a seguir, a fala de G. H. sobre o que considera purificação antes e depois de viver a experiência:

Antigamente purificar-me significaria uma crueldade contra o que eu chamava de "eu", sem saber que "eu" era um acréscimo de mim. [...]. Mas agora, através de meu mais difícil espanto - estou enfim caminhando em direção ao caminho inverso. Caminho em direção à destruição do que construí, caminho para a despersonalização. (LISPECTOR, 1979, p. 169)

Notamos que, após empreender sua viagem aos universos do dentro de si, usando como veículo a barata, G. H. chega a uma conclusão inesperada:

O mundo independia de mim - esta era a confiança a que eu tinha chegado: o mundo independia de mim, e não estou entendendo o que estou dizendo, nunca! nunca mais compreenderei o que eu disser. Pois como poderia eu dizer sem que a palavra 
mentisse por mim? como poderei dizer senão timidamente assim: a vida se me é. A vida se me é, e eu entendo o que digo. E então adoro. - - - - - -. (LISPECTOR, 1979, p. 175)

Após a fusão da protagonista com a barata, a narrativa não consegue expressar o que acontece, apenas oferece pistas de uma compreensão diferente da habitual: "Porque a coisa nua é tão tediosa. Ah, então era por isso que eu sempre havia tido uma espécie de amor pelo tédio. [...]. Porque o tédio é insosso e se parece como coisa mesmo. E eu não fora grande bastante: só os grandes amam a monotonia" (LISPECTOR, 1979, p. 136).

Mudam o enfoque e a percepção, e o sentido circula o dito. Para além da manifestação, a impossibilidade de dizer é confessada: “- Ah, não sei como te dizer, já que só fico eloquente quando erro, o erro me leva a discutir e a pensar. Mas como te falar, se há um silêncio quando acerto? Como te falar do inexpressivo?" (LISPECTOR, 1979, p. 137). Assim, se dizer com a força do vivido não é possível, a protagonista nos desvenda a possibilidade de viver experiência similar pelas vias da arte e do amor físico: "Às vezes - às vezes nós mesmos manifestamos o inexpressivo - em arte se faz isso, em amor de corpo também - manifestar o inexpressivo é criar". (p. 137)

Neste segmento, pretendemos estudar a escrita clariciana à luz dos enunciados de Freud, no artigo Além do princípio de prazer, de 1920, e no livro O mal-estar na cultura, de 1930. A vasta obra de Freud, o pai da psicanálise, permite ao ser humano compreender os mecanismos que atravessam sua própria interioridade para situar-se no mundo exterior, onde se desenvolvem os fenômenos culturais. Neste trabalho, retomamos as noções freudianas que tratam sobre identidade, pulsões e cultura.

Em O mal-estar na cultura, Freud (2010) faz, inicialmente, uma distinção entre civilização e cultura, definindo esta última como "a soma total de realizações e disposições pelas quais a nossa vida se afasta da de nossos antepassados animais, sendo que tais realizações e disposições servem a dois fins: a proteção do homem contra a natureza e a regulamentação das relações dos homens entre si" (p. 87). Em outras palavras, a cultura abrange tanto o controle que o homem exerce sobre a natureza, como o conjunto de regulamentos que regem as relações humanas. Nesse sentido, o ser humano se vê exposto a uma série de policiamentos, e essa alienação diante da repressão inibe seu desenvolvimento. Relacionando os conhecimentos acerca desse conceito com a obra A paixão segundo $G$. $H$., podemos perceber que a personagem possuía uma civilização anterior, a que abandonara para seguir outra forma de vida, na qual não se reconhece mais:

É que eu não estava mais me vendo, estava era vendo. Toda uma civilização se havia erguido, tendo como garantia que se mantivesse que se misture imediatamente o que se vê com o que se sente, toda uma civilização que tem como alicerce 
salvar-se - pois eu estava em seus escombros. Dessa civilização só pode sair quem tem como função especial a de sair: a um cientista é dada a licença, a um padre é dada a licença. Mas não a um a mulher que nem sequer tem as garantias de um título. E eu fugia, com mal-estar eu fugia. (LISPECTOR, 1979, p. 59)

No trecho, podemos analisar, também, as funções sociais nessa civilização: o cientista e o padre, porque tinham "títulos", funções específicas, poderiam sair, ao passo que ela, a mulher, nada possuía que contasse a seu favor, por isso carregava o mal-estar social de sua falta de função, e, sem a devida licença para sair, só lhe restava a fuga. $\mathrm{O}$ ato de fugir sugere que a situação de escombros não é nada confortável. A sociedade é, em si mesma, repressiva, o que impede o homem de ser livre e feliz. Num primeiro momento, parecem simples, mas os mecanismos coercitivos controlam o ser humano de tal forma que, dificilmente, ele consegue liberar a energia instintiva e, por conseguinte, encontrar possibilidades de concretização da felicidade, "de salvar-se".

O mal-estar é produzido, no homem, pela própria impossibilidade humana de transpor o antagonismo entre as exigências da pulsão e as da cultura. Por isso, a cultura e o desenvolvimento do indivíduo necessitam, de certo modo, do controle e da imposição de regras sociais. O indivíduo é sacrificado pela sociedade, porque precisa renunciar à satisfação pulsional (o sexo e a agressividade), a fim de permitir as condições ao desenvolvimento da cultura.

Em A paixão segundo G. H., quando vê o quarto fragmentar-se diante de si, a personagem diz:

O mundo havia reivindicado a sua própria realidade, e, como depois de uma catástrofe, a minha civilização acabara: eu era apenas um dado histórico. Tudo em mim foi reivindicado pelo começo dos tempos e pelo meu próprio começo. Eu passara a um primeiro plano primário [...] na era primeira da vida. (LISPECTOR, 1979, p. 65)

Nesse trecho, há um embate entre civilização e cultura, pois G. H., através da sua própria despersonalização, vê acabar-se, ruir sua antiga civilização humana, a civilização histórica, na qual havia se transformado em apenas um dado histórico. Por isso a personagem afirma estar entrando numa ordem actancial de coisas, no nascedouro de outra forma de vida - a que denomina "primeiro plano primário", ou a "era primeira da vida" -, sujeita a outros processos e a outras leis, onde G. H. vai viver sua experiência. Na opinião do biógrafo americano Moser (2009, p. 385), o que morre em G. H. é a "civilização".

Moser (2009) assim aborda esse fenômeno na obra: “G. H., com seu enredo breve, esboçado, é na verdade o clímax de uma longa busca pessoal" (p. 380). Segundo o autor, "pela primeira vez ela capta a plena violência, a repugnância física, de seu encontro com Deus" (MOSER, 2009, p. 380). Moser compara o livro de nosso 
estudo com A maçã no escuro, apontando duas diferenças cruciais entre ambos: neste, a autora expõe "Como se faz um homem", e em A paixão segundo G. H., "Como se desfaz uma mulher"; Martim, em seu suposto assassinato da esposa, inventa Deus, G. H. vai ao mais repulsivo e inumano (como diz no prefácio: "atravessando o oposto daquilo que se vai aproximar") para "encontrar Deus".

Em A paixão segundo G. H., o leitor é levado a perfazer, juntamente com a personagem, um contínuo processo de perda das faculdades humanas: "Também eu, que aos poucos estava me reduzindo ao que em mim era irredutível, também eu tinha milhares de cílios pestanejando, e com meus cílios eu avanço, eu protozoária, proteína pura" (LISPECTOR, 1979, p. 56-57). Interpretamos o que ocorre no trecho como a transformação de G. H. num protozoário, ainda que tal transformação não alcance a condição formal, que fique apenas no plano do sentir eliminar de si a condição humana. G. H. é uma personagem que se embrenha numa viagem de descoberta ao mais primitivo do seu ser, por meio de um processo de retorno, usando o corpo da barata como veículo.

Segundo Freud, o projeto de atingir a felicidade é irrealizável, por outro lado é também impossível abandoná-lo. Os caminhos do homem passam por três tipos de vínculos: afetivo, satisfação narcísica e realização pela ação concretizada. Em caso de neurose, os sintomas são satisfações substitutivas, um caminho que é perpassado pela atividade criadora, e cada um indica o caminho à sua maneira, pois o paciente neurótico inventa um pouco os próprios sintomas. O desencadeamento de processo neurótico nada mais é do que uma resposta negativa às exigências culturais. No trecho da obra em estudo, evidenciamos a confusão mental da personagem como uma espécie de neurose:

O que foi que me sucedeu ontem? e agora? Estou confusa, atravessei desertos e desertos, mas fiquei presa sob algum detalhe? como debaixo de uma rocha.

Não, espera, espera: com alívio tenho que lembrar que desde ontem já saí daquele quarto, eu já saí, estou livre! e ainda tenho chance de recuperação. Se eu quiser.

\section{Mas quero? (LISPECTOR, 1979, p. 63)}

Com seus sintomas, sua confusão diante dos fatos e o delírio, o neurótico está dando um "basta" à realidade, porque sua suportabilidade à frustração exigida pela cultura, em lugar dos ideais não concretizados, está esgotada. No trecho, podemos nos perguntar: 1) em termos espaciais, a personagem está no deserto, no quarto ou embaixo de uma rocha? Em termos de estado da personagem, ela está presa ou livre? De que ela se recupera? Ela realmente quer o que diz querer?

A salvação pessoal, um processo solitário, muito difícil de ser atingido, é lenitivo para quem o consegue. No entanto, 
é aparentemente impossível libertar as massas da sensação de infelicidade, insatisfação das pulsões, privação da liberdade (de locomoção, ação, pensamento e sentimento). Conforme a protagonista de A paixão segundo G. H., "transcender era antigamente o [seu] esforço humano de salvação" (LISPECTOR, 1979, p. 78), dando a entender que a transcendência corresponderia à capacidade de elevar-se do humano. Entendemos que a protagonista a carregava como sonho de salvação no passado e que no presente narrativo esse sonho já não faz sentido; salvar-se para G. H. passara a prescindir do ato de transcender. Segundo Freud, os que conseguem vencer a tempestade de suas vicissitudes em busca da salvação ficam responsáveis por mostrar o caminho aos demais, os quais se guiam por eles, em meio a dúvidas, tirando algum proveito de seus sentidos e percepções: alguns se salvam sem muita dificuldade da confusão em que os sentimentos os colocam, mas a maioria tateia até o fim de sua vida.

\begin{abstract}
The presence of the cockroach accentuates the drama of consciousness experienced by G. H. that this is a kind of "rite of passage". Rites of passage are usually loaded with crises associated with the anthropological gaze, which could bring enlightenment to another existential dilemma experienced by the character, confirming the experience as an overcoming of steps, based on the causality of before and after. The character lives her passion, a via crucis of abandonment and dissolution only to rediscover, a moment later, within herself, the human race. The presence of the cockroach accentuates the drama of consciousness experienced by G. H. that this is a kind of "rite of passage". G. H. travels down a path opposite to that of culture. Between disgust and wonder, the character can identify within herself a primordial force that feeds the humans we are, and it is in this direction that it moves, seeking to reunite the mythical subject to the forces of nature. The moment of eating the cockroach merges with the primary world, which, she affirms, incorporates the temporalities of past civilizations.
\end{abstract}

Keywords: the drama of language; existence; experience; dissolution; humankind. 


\section{REFERÊNCIAS}

BESSIERE, Jean. Literatura e representação. In: Teoria literária, org. Marc Angenot. Lisboa: Dom Quixote, 1995.

FREUD, Sigmund. Os três ensaios a teoria da sexualidade (1905). In: ___ Obras completas. Trad. Jayme Salomão. Rio de Janeiro: Imago, 1996. v. XI. (Edição Standard Brasileira).

Além do princípio de prazer (1920). In: . Obras com-

pletas. Trad. Jayme Salomão. Rio de Janeiro: Imago, 1996b. v. XVIII. (Edição Standard Brasileira).

O mal-estar na cultura (1929). Trad. Renato Zwick. Porto Alegre: L\&PM, 2010.

LISPECTOR, Clarice. A paixão segundo G. H. 9. ed. Rio de Janeiro: Nova Fronteira, 1979.

A maçã no escuro. São Paulo: Círculo do livro, s.d.

MOSER, Benjamin. No coração selvagem. Revista Carta na Escola, São Paulo, n. 44, p. 36-38, [mar.] 2010.

NUNES, Benedito. ____. O drama na linguagem: uma leitura de Clarice Lispector. 2. ed. São Paulo: Ática, 1995.

SÁ, Olga de. A escritura de Clarice Lispector. Petrópolis: Vozes, 1988.

SANTIAGO, Silviano. A aula inaugural de Clarice. In: MIRANDA, Wander Melo. Narrativas da modernidade. Belo Horizonte: Autêntica, 1999.

Bestiário. Cadernos de literatura brasileira - Clarice Lispector. São Paulo: Instituto Moreira Salles, 2004.

WALDMAN, Berta. Clarice Lispector - A paixão segundo C. L. 2. ed. São Paulo: Editora Escuta, 1992. (Coleção Ensaios). 